\title{
Factors influencing the flooding process of former coal open-pits
}

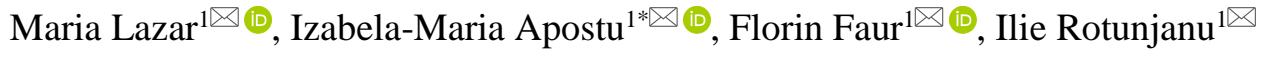 \\ ${ }^{1}$ University of Petroșani, Petroșani, 332006, Romania \\ *Corresponding author: e-mail izabelamaria.nyari@yahoo.com, tel. +40728740003
}

\begin{abstract}
Purpose. This study aims to identify the main factors that influence the flooding process of the remaining gaps of open-pits comprising essentially the velocity and duration of flooding, but also the stability of in situ and dump slopes during and after the flooding and the water quality in order to ensure the takeover of the future function of the land as soon as possible and the safety of objects and local communities.

Methods. Establishing the three categories of factors that influence from a quantitative and qualitative point of view the flooding of the remaining gaps of the open pits. Analysis of the key factors in the flooding process of the remaining gaps, in terms of their contribution to reducing or increasing the flood duration and to reducing or increasing the stability reserve of different types of slopes.

Findings. The interdependence and cumulative action of factors that influence the flooding process of remaining gaps and the stability of in situ and dump slopes materializes in worsening the strength characteristics of rocks and changing the state of stress and deformations in the rock mass.

Originality. The paper provides a detailed description of the key factors and the interactions between these and their influence on the flooding process, stability, and the factor of safety. Their influence and interactions are highlighted through a case study conducted at the Peșteana mining perimeter level.

Practical implications. The flooding of the remaining gaps can cause loss of slope stability during and after the flooding process. Unexpected geotechnical phenomena such as landslides, liquefaction, suffosis, rock falls and/or the water quality of the pit lake can be hazardous to natural and/or anthropic objects and local communities. Safety is essential. Therefore, this study suggests taking into account the most important factors that influence the flooding process when evaluating the flooding possibility of remaining gaps. Engineers, researchers, mine planers, local authorities, and students will have essential information and will know when and where special attention will be needed in the case of flooding of former open-pits.
\end{abstract}

Keywords: open-pits, remaining gaps, flooding, velocity, duration, slope stability, influencing factors

\section{Introduction}

Cessation of exploitation works in the open-pits takes place, mainly, as a result of reserves depletion, but it can also have other causes such as increasing costs of mining, thus becoming economically non-viable. The remaining gaps resulting from the exploitation, in the so-called post-mining stage, can be reclaimed and reused for different purposes, bringing important benefits by supporting the sustainable development of degraded mining lands [1], [2].

The flooding process of the remaining gaps of open-pits can begin with the cessation of the exploitation works if the essential conditions are favorable (existence of groundwater inflow, water inflow from precipitation, or the possibility of water supply from waterbodies or watercourses located in the vicinity of the mining perimeter). Thus, there are pit lakes that can take over different functions, depending on the quality of water and the safety offered by the newly created conditions, such as lakes for recreation, swimming, water reservoir (drinking, industrial), torrent retention basin, research development basin, etc. [3]. Otherwise, when there is no possibility of flooding the remaining gap, or when the flooding process would endanger the safety of objectives and citizens in the areas of influence as a result of the negative effects of water on rocks and slope stability, there are many other options for reusing it as waste deposits, bicycle or motorcycles tracks, performance scenes, industrial museum, etc. [4].

In addition to the existence of water sources that can contribute to the flooding of the remaining gap, the flooding process is influenced by other factors. Among them, the most important are represented by the speed and duration of the flooding process, the stability of the in situ and dump slopes, and the geochemistry of the rocks.

Some researchers have studied the influence of various factors on the flooding process of the remaining gaps [3], [5], [6], but, generally, particular focus was given to factors in- 
fluencing slope stability [7]-[10]. Therefore, in this paper, we aimed at identifying the most important factors influencing the flooding process taking into account both the factors influencing the speed and duration of this process and those influencing the stability of the slopes, as they cannot be neglected and safety must prevail.

\section{Materials and methods}

According to the specialized literature [10]-[17], there are numerous factors that intervene in the flooding process. The main factors that influence the flooding process of the remaining gaps of open-pits were grouped into two categories:

1) factors influencing the velocity and duration of the flooding process;

2) factors influencing the stability of in situ and dump slopes during and after flooding the remaining gaps;

3)geochemistry of the rocks.

\subsection{Factors influencing the velocity and duration of the flooding process}

The main hydrogeological factors that influence the velocity and duration of flooding process of the remaining gaps are:

- the presence of aquifer formations in the open-pits cover and the character of water resources;

- aquiferity of rocks (hydrogeological characteristics and flow conditions);

- hydrodynamic parameters of groundwater flow $(\Delta H$, $\left.\Delta P, I_{c r t}, V_{c r t}, V_{a d m}\right)$.

The presence of aquifer formations. The process of flooding the remaining gaps of open-pits by groundwater inflow is conditioned, first of all, by their existence and the possibility of their migration to these places.

The existence of groundwater is dependent on the presence of porous rocks, able to ensure both water storage and circulation. Geological formations capable of storing groundwater in rock pores and ensuring their circulation are called aquifer formations. Consequently, the process of natural flooding of the remaining gaps of the open-pits is dependent on the existence of aquifers in their cover or in the areas adjacent to the open-pits.

These can be in the form of aquifer layers (phreatic or captive), lenses, horizons, and complexes. Their existence is characteristic of the inferior coal deposits (lignite and brown coal).

The volume and inflow of groundwater is dependent on the extent and thickness of aquifers and the nature of water resources. Of particular importance are the dynamic resources, both through the possibilities of drainage and through the possibilities of regeneration in time and space.

Important dynamic inflows mean possibilities for faster flooding of gaps, but also stronger hydrodynamic currents, with a major influence on the formation of suffosis gaps and undermining of slopes by landslides phenomena. Consequently, the stability of the slopes of the remaining gaps may be affected under these conditions.

The aquiferity of the rocks influences the conditions of flow and drainage of groundwater and depends on the hydrogeological characteristics of the rocks [11], [12]. From a granulometric point of view, aquifer rocks can show a significant variation, from dusty or clayey sands to coarse sands or mixtures of sands with gravels and boulders, depending on the tectonic cycle in which marine transgressions and regressions occurred [18], [19]. Depending on this variability, to which are added the degree of compaction or cementation of the rocks in the geological structure of the region, the size and volume of the pores vary, and the porosity can be closed or open, without or with groundwater circulation possibilities due to level or pressure differences between the supply or storage area and the drainage area [12].

The aquiferity of the rocks and therefore the groundwater circulation is ensured by the existence of supracapillary pores $(\phi>0.508 \mathrm{~mm})$ and open type porosity, when the gravitational force due to the level difference is higher than the capillary forces or surface tensions created by water contact with the mineral skeleton of the rock.

The category of rocks with supercapillary pores includes all types of medium and coarse sands, where the water circulation is easy. In the category of fine-grained rocks (fine sands, clayey or dusty sands) the groundwater circulation is made in more difficult conditions and is conditioned especially by the existence of hydrostatic or hydrodynamic pressures.

Hydrodynamic parameters. Due to the low hydraulic gradients, the natural flow of groundwater through the aquifers takes place in a laminar regime. Changing the flow regime in transient or turbulent regime can occur only in the aquifer discharge area and over relatively short distances under the influence of hydrodynamic parameters of groundwater flow: level $(\Delta H)$ and pressure $(\Delta P)$ difference, hydraulic gradients ( $I$ și $\left.I_{c r t}\right)$ and flow rate $\left(v_{c r t}\right.$ și $\left.v_{a d m}\right)$.

Level difference $\Delta H$ or pressure difference $\Delta P$ occur when the supply or accumulation area is at higher levels than the natural or artificial drainage area of the aquifer. By reporting the level difference $\Delta H$ on the flow direction at the distance $(L)$ between the points (areas) to which the level difference is expressed, the hydraulic gradient $(I)$ is obtained. The hydraulic gradient represents the analytical expression of the forces acting on the hydrodynamically active water (circulating water under the action of the gravitational field from areas with higher energy to areas with lower energy) [10], [12]-[15].

The hydraulic gradient $(I)$ in the case of the natural flow regime has low values $(I \leq 0.1-0.2)$ and ensures the laminar flow, a regime that does not affect the granular rocks structure and the stability of the slopes, as the flow velocity is in the range of $\mathrm{cm}$ or $\mathrm{mm} / \mathrm{s}$, and the hydrodynamic pressure is very low. For sandy rocks, the transition to turbulent flow, which can affect the structure of the rocks and possibly the stability of the slopes, can occur when the groundwater flow velocity exceeds the critical velocity. In the case of aquifer sands, depending on their granulometry and porosity, $v_{c r t}=0.2-1.2 \cdot k_{f}$, where $k_{f}$ - the filtration coefficient in $\mathrm{m} /$ day or $\mathrm{cm} / \mathrm{s}$ ).

In order to avoid suffosis phenomena in the groundwater drainage areas, an admissible velocity $v_{a d m} \leq 0.8 v_{c r t}$ is recommended [12], [15], [20], which in the conditions of the remaining waters from the open-pit slopes is achievable as a result of the decrease of potential energy due to natural water drainage or dewatering works.

\subsection{Factors influencing the stability of in situ and dump slopes during and after flooding of remaining gaps}

The main factors that influence the stability of artificial and natural slopes during and after flooding of remaining gaps can be grouped into 6 categories:

- geological and hydrogeological factors;

- natural mechanical and geomechanical factors;

- hydro-meteorological and climatic factors;

- anthropogenic (technogenic) factors;

- seismic factors;

- biotic factors. 
The geological factors refer to the geological structure of the region, the nature of in situ rocks or of mixtures of rocks in dumps, the presence of contact or stratification surfaces, the presence of faults, cracks, fissures etc. All these represent surfaces of minimum resistance and, as a rule, they constitute potential sliding surfaces. The direction and inclination of layers and crack systems also have an important influence. If their slope coincides with the slope inclination, they may constitute potential slip surfaces.

It is necessary to determine the angle between the inclination of the layers/cracks and the inclination of the slope. The stability of a massif is maximum when the slope inclines in the opposite direction to the inclination of the layers or is perpendicular to the direction of the layers and decreases to a minimum value when the direction of the slope is parallel to the direction of the layers.

In the case of dumps, the nature and structure of the mixture of rocks intervene, as well as the way of twinning between the dumped material and the dump base or with the final slopes of the remaining gap.

The hydrogeological factors refer to the presence of aquifer formations in the rock structure. The presence of water in rocks influences the state of unitary efforts by variation of rocks humidity and modification of their geotechnical characteristics, manifestation of pore water pressure in saturation conditions, manifestation of hydrodynamic pressure in aquifers, manifestation of suffosis or liquefaction phenomena, etc.

In the case of mining perimeters intersecting aquifer formations, level variations occur in both phreatic and deep aquifers, being generally determined by the dewatering works performed and are influenced by the restoration capacity of the aquifer resources.

In the case of dumps, the hydrogeological factor is present only under the conditions of the formation of an aquifer structure during the construction of the dumps or their exploitation. During the flooding of the open-pits, phenomena of liquefaction of the dumped material may occur, especially when the sandy fraction predominates.

In the twinning areas of the inner dumps with the natural land, the natural drainage of the aquifer formations takes place. These waters (to which are added the rainwaters) accumulate in the body of the dump, and depending on the nature of the waste material, the drainage capacity of the dump water may be higher or lower.

Lack of drainage or reduced drainage possibilities determine the water level in the dump to raise. The accumulation of water in the dump body causes the volumetric weight of the rocks to increase, and the pore water pressure determines the worsening of the resistance characteristics of the rocks (decreasing the cohesion and the internal friction angle) by reducing the effective pressure on the sliding surface.

Natural mechanical and geomechanical factors refer to surface morphodynamic phenomena, dependent on the nature and strength characteristics of rocks. Natural mechanical factors are represented by the action of meteoric water, running or stagnant water and the action of atmospheric currents. These can cause erosion phenomena on slopes or at their base. Erosion can lead to the manifestation of landslides as a result of affecting the state of stress in the massif. Geomechanical factors are closely related to geological factors and refer to the structure and strength characteristics of rocks in the final slopes of open-pits or dumps. In order to carry out stability studies, retro-analyzes or predictions of land- slides, it is necessary to take representative samples and analyze in detail the strength characteristics of rocks, so that their behavior can be analyzed under different stress conditions under the influence of different hydrometeorological, climatic or other factors.

Hydrometeorological and climatic factors refer to the presence and intensity of precipitation, freeze-thawing phenomena, temperature variations, the presence of drought, the phenomenon of contraction-swelling, etc.

Precipitation leads to an increase in the amount of water infiltrated into the soil and subsoil. As a result, the humidity of the rocks increases, the state of consistency of the weakly cohesive rocks can change, the volumetric weight increases, and in conditions of saturation of the granular rocks the pore water pressure and possibly the hydrodynamic pressure are manifested. All this leads to the reduction of the stability reserve of the massif.

The unfavorable influence of precipitation, by increasing the humidity of the rocks, by creating phreatic layers and the pore water pressure, is manifested especially in dumps where the disaggregated structure of the rock mixture facilitates water infiltration.

Groundwater level variations occur under the influence of hydrometeorological and climatic factors in extreme situations, with long-term rainfall alternating with dry periods. They mainly affect shallow aquifer formations and respectively, the dumps. In the case of deep aquifers, the climatic conditions of a region have an insignificant influence. Deep aquifers can be affected quantitatively and qualitatively only in case of long-lasting drought periods.

Freeze-thaw phenomena occur as a result of temperature variations. Water that enters the pores and cracks of rocks at low temperatures freezes and expands, increasing its volume by about $9 \%$. The increase of the water volume as a result of the expansion, determines the manifestation of an additional pressure in the pores and cracks of the rocks, of over $2000 \mathrm{kN} / \mathrm{m}^{2}$ [12]-[14], [20], increasing the degree of cracking, under the action of which the states of tensions in their mass also change. Repeated freeze-thaw processes cause fragmentation and disaggregation of rocks, which worsens their strength characteristics.

Drought leads to the manifestation of extreme phenomena of rock contraction, and major problems occur in the case of clay rocks.

Clayey rocks show an important contraction-swelling potential due to humidity variations. They are part of the category of lands with high swellings and contractions. The increase or decrease of the thickness of the adsorbed water cover is always accompanied by an extension or contraction of the soil structure, by changing the distance between the particles, resulting in significant variations in volume, even for small variations of humidity.

The anthropogenic factor refers to the morphological, structural or resistance changes of the rocks, which appear as a result of the development of technological activities in the quarries (excavation, transport, dumping). These require substantial changes in shape, geometry, efforts and stresses, as well as deformations in the in situ massifs or in the dumps. The geometry of the final slopes of the remaining gaps is a key element in ensuring their stability under flooding conditions. Not complying with the designed geometrical elements of the slopes and systems of slopes, or the improper execution of excavation and dumping works, in the area of the 
remaining gaps, may be the cause of deformations or landslides in the flooded remaining gaps [12]-[14].

The remaining gaps are, most of the times, bordered on three sides by the final slopes of the open-pit and on one side by the slopes of the inner dump. Unlike the in-situ rocks the waste rocks in the dumps are loose rocks, whose strength has been affected by excavation, transport and dumping and has a higher risk of sliding under the influence of various external factors.

In the case of flooding of the remaining gaps of former open-pits, a great influence on the stability of the slopes has the dynamics of water accumulation, by varying water levels and especially by currents or waves that form under the influence of prevailing winds, or large tributaries or effluents. The erosive action of the waves, associated with the phenomenon of softening of the rocks in the slopes, can be other causes associated with the anthropogenic factor influencing the stability of the component rocks of the slopes.

The seismic factor is manifested in the case of earthquakes or seismic phenomena induced by the execution of controlled or uncontrolled explosions, vibrations produced by the operation and circulation of technological equipment and installations or high-capacity road and rail traffic.

Seismic forces are manifested as volume forces (in all directions), and of these vertical forces reduce the normal effective pressure on the sliding surface, and horizontal forces act as pushing forces having the most unfavorable effect on slopes stability [12], [13].

In the case of earthquakes, the loss of balance of slopes, followed by landslides, is not caused by a reduction in the shear strength of rocks, but an increase in landslide forces, which increase with the intensity of the earthquake.

The influence of vibrations must be perceived in terms of the sum effect of periodic repeated vibrations, which contribute to the reduction of rock strength. In the case of clayey rocks with high plasticity, under the influence of vibrations, they can pass into a thixotropic state, turning into a fluid mass, and after the cessation of vibrations the fluid acquires the properties of a gel [20].

The biotic factor is dependent on the presence of vegetation on slopes, although it can lead to a negative effect due to the occurence of overloads, also has a positive influence on the stability of slopes of remaining gaps, as vegetation anchors the top soil, soft and hard rocks, prevents the manifestation of erosion phenomena, intercepts a part of the rainfall, captures the energy of raindrops, reduces the speed of surface runoff, behaves like a filter that prevents the transport of sediments, etc.

\subsection{Geochemistry of the rocks}

The geochemistry of the rocks is the main factor affecting the water quality of a pit lake. The water of a pit lake can be of high quality, clean, fresh, but in some cases it is acidic, saline, or even toxic. Depending on the water quality of pit lakes opportunities or, on the contrary, risks to local communities and ecosystems could arise.

Large scale dewatering during the mining activities and long-term oxidation of minerals conducts to chemical reactions and contamination of water with sulphates, heavy metals, and other elements. In the case of open-pits, two types of minerals exist depending on the stage of mining:

- primary minerals such as silicates, sulphides, and carbonates that exist prior to open-pit mining exploitation;
- secondary minerals such as carbonates, oxides, hydroxides, and sulphates of iron, aluminium, manganese, calcium, and other elements as a result of exposure of rocks to atmospheric conditions [17].

Strongly acidic waters represent the main problem related to the water quality in former coal pit lakes in case of their flooding. Pyrite oxidation processes are the most critical concerning to the final water quality.

\section{Results and discussions}

A total of 10 factors that influence the flooding process of remaining gaps of open-pits were taken into account and a study was conducted on the case of Peșteana mining perimeter located in Romania to evaluate their influences in a concrete case.

\subsection{The presence of aquifer formations in the open- pits cover and the character of water resources}

From a hydrogeological point of view, in the area of the Peșteana mining perimeter (South Peșteana and North Peșteana) the aquifer formations are divided into:

- phreatic aquifers;

- captive aquifers with free level;

- captive aquifers with water under pressure, with ascending or artesian character.

The phreatic aquifer horizon is located in the Quaternary alluvial deposits form the meadow and the lower terraces of the Jiu Valley. This horizon is very well developed in the South and North Peşteana mining perimeters, being located in the Jiu river meadow. Captive aquifer horizons are located in the intercalations and sandbanks from the base and roof of the lignite layers. Hydrogeological exploration boreholes have highlighted several deep aquifer horizons with variable flows due to the granulometric constitution of the sands. The aquifer horizons do not have a continuous spread, their lentiliform character being highlighted by different studies [18], [19].

The groundwater bodies developed in the area are "Groundwater body - code ROJI05 - Meadow and terraces of Jiu river" and "Deep groundwater body from the Pliocene formations - code ROJI07" (Fig. 1).

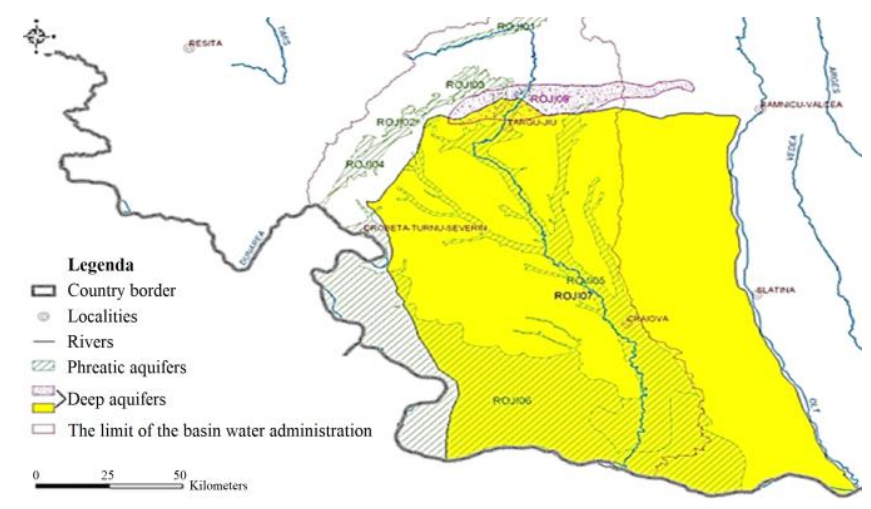

Figure 1. Delimitation of groundwater bodies within the Jiu Water Basin Administration [18], [19]

The thickness of the alluvial deposits in the South Peşteana perimeter varies between $3.75-19 \mathrm{~m}$. The thickness of the aquifer layers located in the roof of the XII lignite layer varies between $2-15 \mathrm{~m}$ and of the aquifer located between $\mathrm{X}$-XII lignite layers is developed in the form of lenses with thicknesses of 2.5-6.5 m, rarely up to $10-12 \mathrm{~m}$. 
Significant inflows of water from aquifers, Jiu River, rainfall, have contributed to the flooding of the remaining gap of the South Pesteana open-pit. South Pesteana open-pit is flooded in a proportion of $70-80 \%$, and the water level is maintained at the current level through the pumping stations to prevent the flooding of the $\mathrm{II}^{\text {nd }}$ step of the inner dump where the exploitation equipments are deposited.

According to the studies carried out, in the case of North Pesteana open-pit we meet the same hydrogeological conditions. Based on this and other aspects such as the short distance between the two open-pits, similar hydrological and hydrographic conditions, etc., it is forecasted that the flooding of the North Pesteana open-pit will take place naturally, in an acceptable period of time.

In the case of the South Pesteana open-pit, during flooding, only the water level in the lake was monitored. Following the visual analysis performed in the field, no possible changes were observed such as negative geotechnical phenomena. The situation of the submerged slopes is unknown, but it is certain that no large-scale geotechnical phenomena have taken place. In the case of the North Pesteana open-pit, areas of pluvial erosion, cracks, fissures, superficial landslides and suffosis phenomena were observed. These areas may be areas of minimal resistance favoring the manifestation of the sliding phenomena of large scale.

\subsection{Aquiferity of rocks (hydrogeological characteristics and flow conditions)}

The waste material resulted from the exploitation of lignite in the Pesteana perimeter consists of clays, sands, dust, marls, gravels and boulders, as well as mixtures from these rocks. These types of rocks are rocks with open porosity through which water circulates gravitationally (in the case of sands, gravels and boulders) or under pressure (in the case of clays, marls).
In Figure 2 are presented 2 stratigraphic columns representative for the North Peșteana perimeter, and in Table 1 are centralized the thickness of the waste rocks depending on their nature. (a)

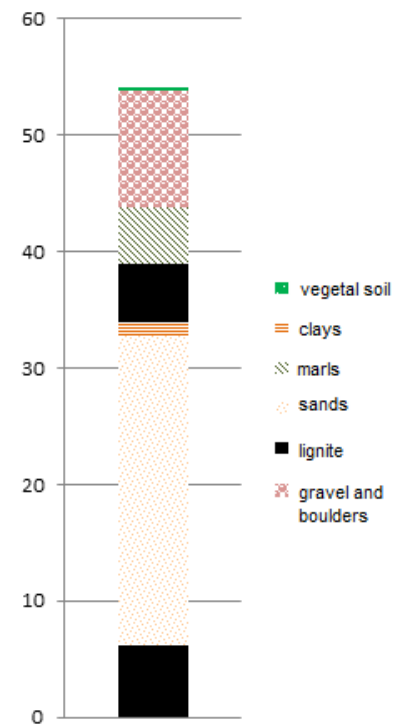

(b)

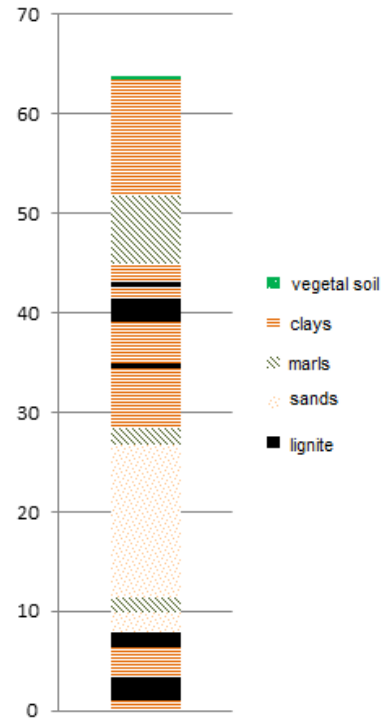

Figure 2. Stratigraphic columns representative for the North Peșteana perimeter [20]: (a) section S1; (b) geotechnical borehole F4

The large thickness of the aquifer layers (sandy rocks, gravels and boulders) is observed. The large variation of the flow parameters within the Peşteana perimeter confirms the high heterogeneity of the granulometry (especially in the case of alluvial deposits), which sometimes indicates a high aquiferity [18], [19].

Table 1. The thickness of the waste rocks depending on their nature

\begin{tabular}{cccccccc}
\hline \multirow{2}{*}{$\begin{array}{c}\text { Geotechnical } \\
\text { borehole }\end{array}$} & \multirow{2}{*}{$\begin{array}{c}\text { Borehole } \\
\text { depth, } \mathrm{m}\end{array}$} & $\begin{array}{c}\text { Cumulative } \\
\text { thickness } \\
\text { (excluding lignite) } \mathrm{m}\end{array}$ & $\begin{array}{c}\text { Gravel, } \\
\text { boulders }\end{array}$ & Sands & Clays & Marls & Vegetal soil \\
\cline { 5 - 8 } & 50.88 & 44.61 & 0.00 & 25.82 & 11.50 & 6.60 & 0.69 \\
S1 & 49.32 & 44.29 & 0.00 & 32.32 & 7.25 & 4.32 & 0.40 \\
F1 & 46.24 & 42.45 & 0.00 & 26.46 & 11.03 & 4.56 & 0.40 \\
F2 & 54.20 & 42.89 & 10.01 & 26.57 & 1.14 & 4.76 & 0.40 \\
F3 & 58.00 & 48.28 & 4.40 & 22.97 & 14.46 & 6.05 & 0.40 \\
S2 & 63.96 & 56.94 & 0.00 & 17.49 & 29.03 & 10.02 & 0.40 \\
F4 & 60.28 & 56.98 & 9.68 & 16.82 & 24.15 & 5.75 & 0.57 \\
S3 & 39.76 & 37.42 & 8.44 & 19.33 & 6.22 & 2.84 & 0.60 \\
F5 & 19.48 & 18.10 & 5.95 & - & 6.39 & 4.96 & 0.80 \\
F6 & 391.96 & 38.48 & 187.79 & 111.16 & 49.86 & 4.66 \\
Total & 442.120 & & & & & & Thickness, m \\
\hline
\end{tabular}

\subsection{Hydrodynamic parameters of groundwater \\ flow ( $\left.\Delta H, \Delta P, I_{c r t}, V_{c r t}, V_{a d m}\right)$}

In the South Peșteana mining perimeter no suffosis phenomena were recorded as a result of exceeding the critical speed of groundwater flow, neither during the exploitation period, nor during the flooding of the remaining gap.

Instead, in the North Peşteana perimeter several suffosis zones were reported (in the interval of layers VII-VIII of lignite, on the slopes of the III ${ }^{\text {rd }}$ and $\mathrm{IV}^{\text {th }}$ steps of the open-pit (Figs. 3 and 4), which during the exploitation are eliminated as the work front advances, but during the flooding it is possible to cause a number of geotechnical problems.

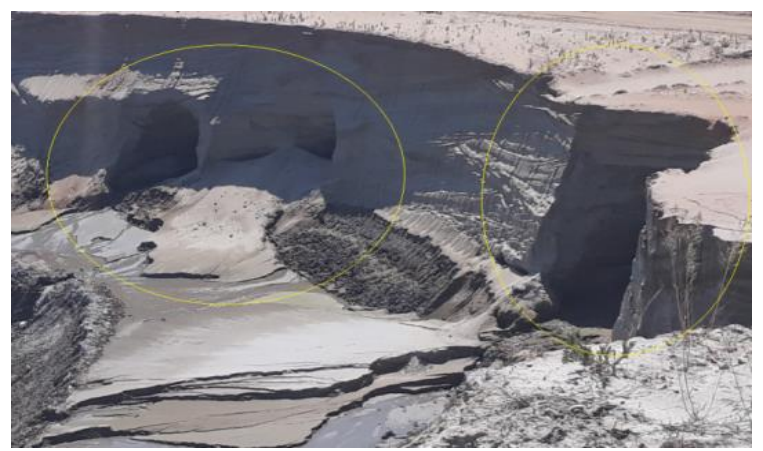

Figure 3. Suffosis areas on the III ${ }^{\text {rd }}$ step of the North Peșteana open-pit [20] 


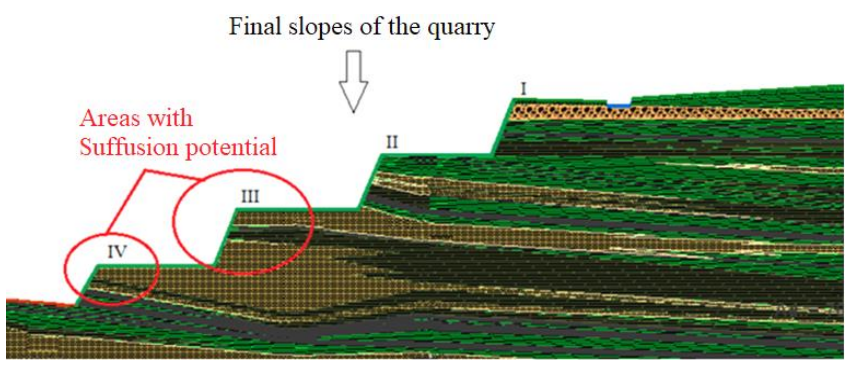

Figure 4. Areas with suffosis potential [18]

Based on existing boreholes and data (hydrostatic level, piezometric level, piezometric pressure) for the North Peșteana perimeter, the hydraulic gradients, characteristic of phreatic aquifers and for the aquifer located between the VII-VIII lignite layers, were determined (layers of interest; Fig. 5).

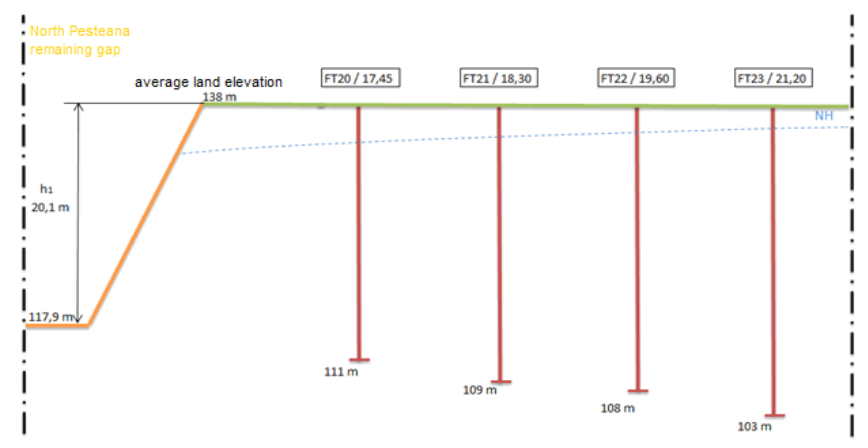

Figure 5. Hydrostatic level of phreatic
The values obtained (for the phreatic aquifer: $I=0.0057$ $0.0107, I_{\text {med }}$ hreatic $=0.007619$; for the aquifer located between the VII-VIII lignite layers: $I=0.010478-0.029485$, ImedVII$V I I I=0.019982[20])$ indicates that the drainage of groundwater takes place in a laminar regime, a favorable condition that does not affect the rock structure and the manifestation of suffosis phenomena. The change of the flow regime in transient or turbulent regime occurred only in the area of discharge of aquifers and over relatively short distances, an area where several suffosis phenomena were identified, but of small magnitude. For the South Peșteana perimeter the available data were insufficient for the calculation of hydraulic gradients, but considering its location in relation to the North Pesteana perimeter, the extent of the aquifer horizon, the absence of suffosis processes, it can be appreciated that the flow took place in laminar regime (I $\leq 0.1-0.2$ ). Table 2 shows the hydrodynamic parameters of groundwater, determined on the basis of known data and calculation formulas $\left(v=I \cdot k_{f}, v_{c r t}=(0.2-1.2) \cdot k_{f} ; v_{a d m} \leq 0.8 v_{c r t}\right)$.

The maximum groundwater flow velocity was determined taking into account the maximum values of the hydraulic gradients, respectively of the filtration coefficients, as these values are of special interest. The flow rate shows important variations due to the different nature of the rocks and their non-uniform location.

Major problems can occur after the cessation of exploitation in the North Peșteana perimeter if the suffosis phenomena are manifested at the base of the slope involving the displacement of the rock mass above the suffosis zone. Accelerating the flooding process and submerging these slopes, applying stabilization measures or controlling the water inflow to the remaining gap can considerably reduce the risk of suffosis/sliding.

Table 2. The hydrodynamic parameters of groundwater

\begin{tabular}{|c|c|c|c|c|c|}
\hline Perimeter & Horizon & $\begin{array}{l}\text { Filtration coefficient, } \\
\qquad k_{f}, \mathrm{~m} / \mathrm{day}\end{array}$ & $\begin{array}{c}\text { Maximum flow } \\
\text { velocity }, \\
v=I_{\max } \cdot k_{\text {fmax }}, \mathrm{m} / \text { day }\end{array}$ & $\begin{array}{l}\text { Critical velocity, } \\
v_{c r t}, \mathrm{~m} / \text { day }\end{array}$ & $\begin{array}{c}\text { Admissible velocity, } \\
v_{a d m}, \mathrm{~m} / \text { day }\end{array}$ \\
\hline \multirow{3}{*}{$\begin{array}{l}\text { South } \\
\text { Pesteana }\end{array}$} & Phreatic & $3.8-96$ & $\leq 0.38-19.2$ & $0.8-115.2$ & $\leq 0.64-92.16$ \\
\hline & $\begin{array}{c}\text { from the roof } \\
\text { of XII lignite layer }\end{array}$ & 0.63 & $\leq 0.063-0.126$ & $0.126-0.756$ & $\leq 0.101-0.605$ \\
\hline & $\begin{array}{c}\text { between the X-XII } \\
\text { lignite layers }\end{array}$ & $0.1-4.8$ & $\leq 0.01-0.96$ & $0.02-5.76$ & $\leq 0.016-4.608$ \\
\hline \multirow{2}{*}{$\begin{array}{l}\text { North } \\
\text { Pesteana }\end{array}$} & Phreatic & $3.8-43$ & 0.43 & $0.76-51.6$ & $\leq 0.608-41.28$ \\
\hline & $\begin{array}{c}\text { between the VII-VIII } \\
\text { lignite layers }\end{array}$ & $0.62-1.71$ & 0.05 & $0.124-2.052$ & $\leq 0.0992-1.6416$ \\
\hline
\end{tabular}

If suffosis phenomena occurred during the flooding of the remaining gap of the South Peșteana open-pit, then the risk decreased with the submergence of susceptible slopes. Being flooded in a significant proportion the remaining gap no longer presents major risks in terms of the manifestation of suffosis phenomena.

\subsection{The geological and hydrogeological factors}

The exploration researches revealed a complete succession of sedimentary formations, starting from the Paleogene and ending with the Superior Pliocene, over which the Quaternary deposits are located, being composed of lignite layers of different thicknesses (from a few centimeters to several meters) and variable extensions, separated from each other by sterile, soft, cohesive and non-cohesive rocks (mostly clayey and sandy rocks) [21].

Also, several tectonic accidents (Bălteni fault, Valea cu Apa fault and Peșteana fault) were highlighted with large falls in the northern part of the Peșteana perimeter and with some local undulations in the southern part of the perimeter.

According to the analyzes performed for the North Peșteana open-pit, it was found that the in-situ layers inclines in the opposite direction to the inclination of the slopes (or are horizontal - Figure 6) which represents a favorable situation in terms of slope stability. The thick layers of sandy rocks in the III ${ }^{\text {rd }}$ and IV ${ }^{\text {th }}$ steps of the open-pit have a low resistance, but their inclination ensured an acceptable stability factor.

The inner dumps (of the South and North Peșteana perimeters) extend from north to south as the work fronts advance and cover the base of the open-pits. These dumps are twinned with the natural land. The contact surface between a dump and the natural land can be a potential sliding surface. Also in the case of the North Peșteana perimeter, it was observed that a part of the foundation of the dump inclines towards the base of the open-pit (forming a potential polygonal sliding surface - Figure 7). 


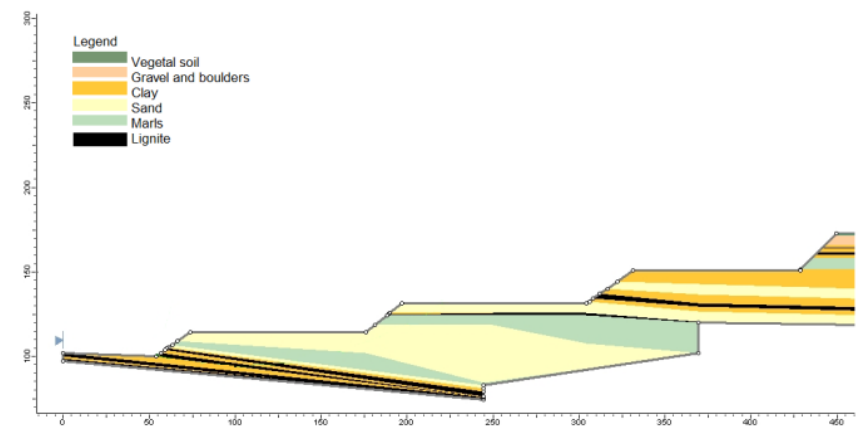

Figure 6. In-situ layers inclination (final slopes of North Peșteana open-pit)

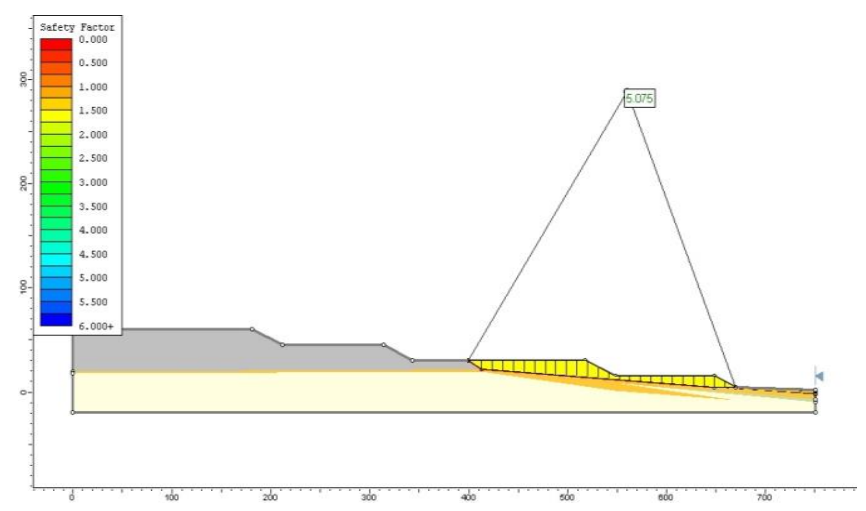

Figure 7. Stability analysis for the system of steps I-II of the inner dump (North Peșteana perimeter; natural drainage conditions)

However, the stability analyzes indicated an important reserve of stability of the slopes, and this fact is mainly due to the favorable geometric characteristics (heights and slope angles with low values).

In the South and North Peșteana perimeters, no large landslides were recorded, only superficial landslides, which did not endanger the safety of people and/or equipment in the mining perimeters. Laboratory analyzes performed on sandy and clayey rocks clearly indicate the increase in volumetric weight and the reduction of cohesion and the angle of internal friction, thus worsening the geotechnical characteristics under the influence of water (Fig. 8).

The sandy fraction existing in the North Peșteana inner dump $(\approx 48 \%)$, in the conditions of raising the water level in the dump during the flooding and the manifestation of pore water pressure, can lead to liquefaction problems. The problematic situation occurs when the water in the lake comes in contact with the final slopes of the dump where sandy rocks predominate, as the waste rocks are not represented by a uniform mixture. The creation of favorable conditions in these areas with the flooding of the remaining gap (loose and saturated sandy rocks and the manifestation of water pressure in the pores) can favor the occurrence of the liquefaction phenomenon. According to studies, it was estimated an average risk of liquefaction [22]. So far, in the South and North Peșteana perimeters, no liquefaction phenomena have been recorded.

If the groundwater flow velocity, in the case of sandy rocks, is high and exceeds the critical velocity, then the fine sand particles are entrained under the action of hydrodynamic pressure, which can lead to the manifestation of suffosis phenomena. The hydraulic gradients indicate that the drainage of groundwater takes place, generally, in a laminar regime. (a)

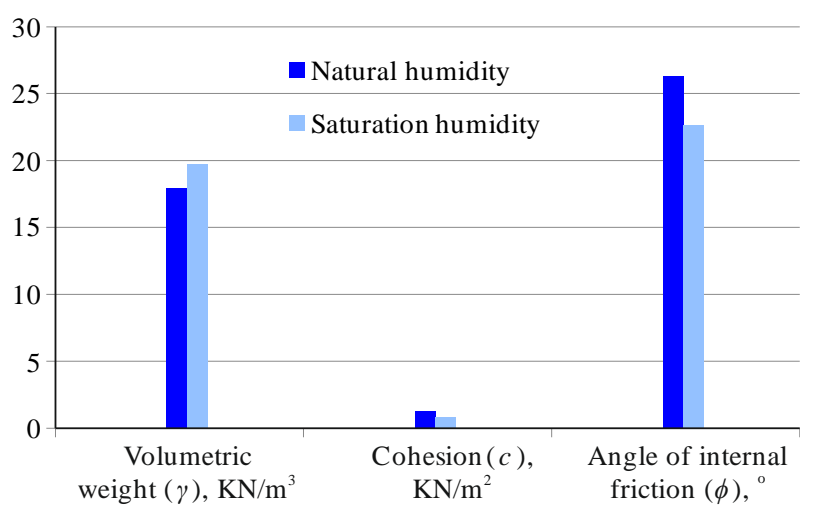

(b)

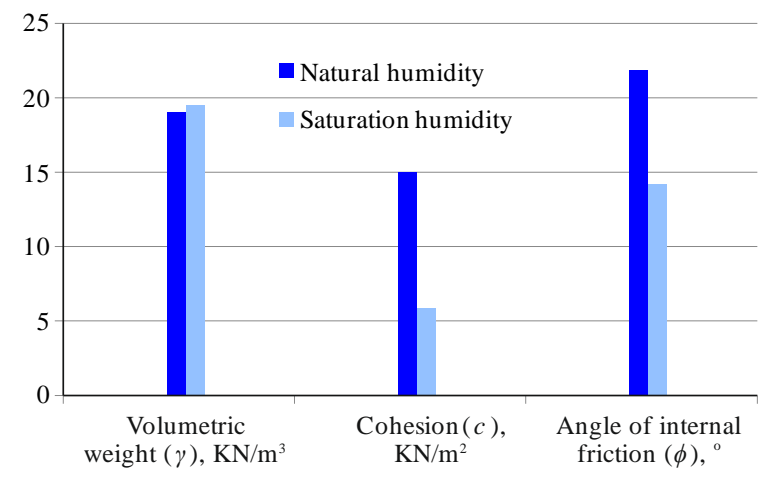

Figure 8. Variation of geotechnical characteristics in sandy and clayey rocks: (a) sandy rocks; (b) clayey rocks

\subsection{Natural mechanical and geomechanical factors}

During the lignite exploitation in the South Peșteana perimeter, on the slopes of the open-pit and of the dump, pluvial erosion was manifested, but following the abandonment of the mining works and the revegetation of the slopes during the years, the erosion traces were wiped out (Fig. 9).

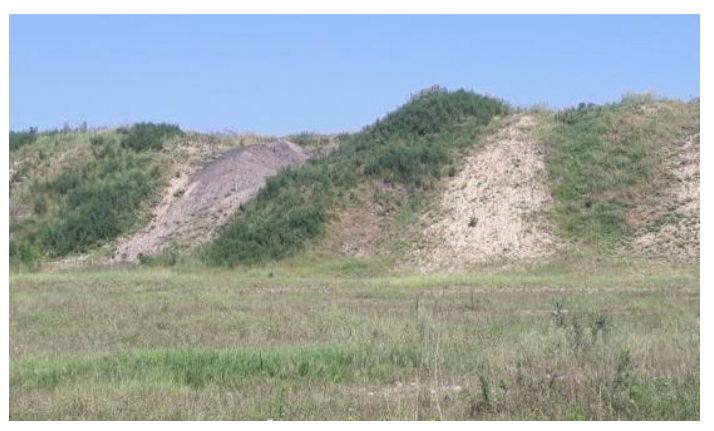

Figure 9. Inner dump slope (South Peșteana perimeter)

In the North Peșteana mining perimeter, the manifestation of erosion phenomena was observed on the in-situ and dump slopes (Fig. 10). Pluvial erosion generally manifested in the form of small ditches with depths $<50 \mathrm{~cm}$ (gutters), and the eroded material was transported and deposited at the base of the slopes.

Pluvial erosion can lead to landslides as a result of affecting the state of stress in the massif, but in the studied perimeters there were no large landslide phenomena caused by erosion. 
(a)

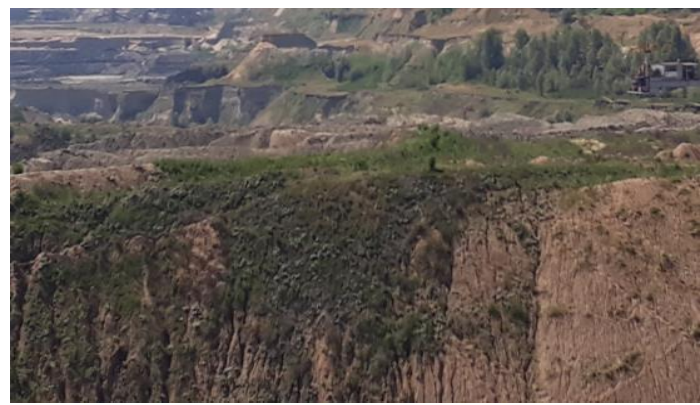

(b)

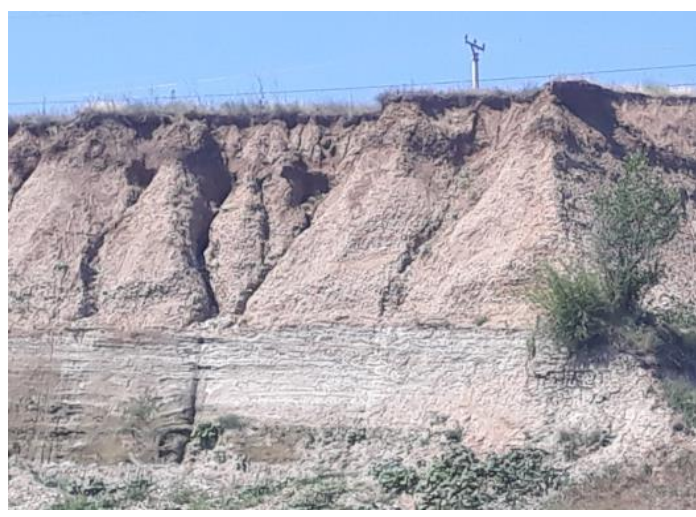

Figure 10. Pluvial erosion: (a) inner dump slope; (b) in-situ slope right

\subsection{Hydrometeorological and climatic factors}

During periods of drought, under the effect of tensile stresses that occur, cracks are formed and then facilitate the penetration of water and the creation of areas of minimal resistance that can affect the stability of the slopes. An example of crack induced by dry periods of a in situ slope, located on the III ${ }^{\text {rd }}$ in situ step of North Peșteana perimeter, is presented in Figure 11.

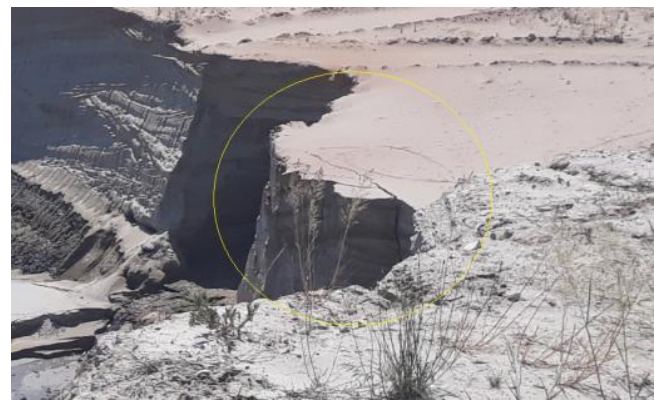

Figure 11. Deep crack in the IIIrd step of the North Peșteana open-pit

\subsection{The anthropogenic factor}

The average depth of the remaining gap of the South Peşteana open-pit is $38 \mathrm{~m}$, and of the remaining gap of the North Peşteana open-pit is $80 \mathrm{~m}$. Regarding the final steps, 2 in situ steps and 4 dumping steps were designed for the South Peșteana open-pit and 4 in situ and dumping steps for the North Peșteana open-pit.

According to the existing reports [18], [19], the stability of the slopes of the open-pits and inner dumps was ensured by respecting the following geometric elements:
1) for South Peșteana open-pit:

- in-situ steps:

- step height: $20 \mathrm{~m}$;

- slope angle: $45^{\circ}$;

- safety berms: $50-150 \mathrm{~m}$;

- general slope angle: $14^{\circ}$;

- dumping steps:

- step height: 15-20 m;

- safety berms: min. $100 \mathrm{~m}$;

- general slope angle: $3^{\circ}$;

2) for North Peșteana open-pit:

- in-situ steps:

- step height: $20 \mathrm{~m}$;

- slope angle: $45^{\circ}$;

- safety berms: $100 \mathrm{~m}$;

- general slope angle: $4^{\circ}-5^{\circ}$;

- dumping steps:

- step height: max 15 m;

- safety berms: min. $100 \mathrm{~m}$;

- general slope angle: $7^{\circ}$.

\subsection{The seismic factor}

According to the studies performed, in the area of Peşteana perimeter there were no notable earthquakes (with epicenter in the studied area or within the current limits of Romania) that would cause significant effects, so statistically, it is unlikely that earthquakes in the country will have major negative effects in this region [18], [19], [22]-[25]. Consequently, the seismic influences in the thixotropy process are insignificant.

The vibrations resulting from the operation and traffic of heavy machinery in the open-pit or car traffic on the county road DJ 674 and the national road DN 66 can be neglected. Blasting by explosions is not practiced, so no vibrations were recorded due to this kind of operations.

Even if these significant vibrations, generated by the circulation of heavy machinery, act only during the period of activity of the mining operation, and at the end of the mining activity their action is reduced, the negative effect accumulated during the active period cannot be eliminated. The effect of vibrations is felt through changes in the strength characteristics of rocks (in the sense of their worsening) [22].

\subsection{The biotic factor}

Following the cessation of the exploitation activity in the South Peșteana open-pit, the vegetation, especially grassy, bushes and rarely trees, settled spontaneously on the final steps (on slopes and berms - Figure 12).

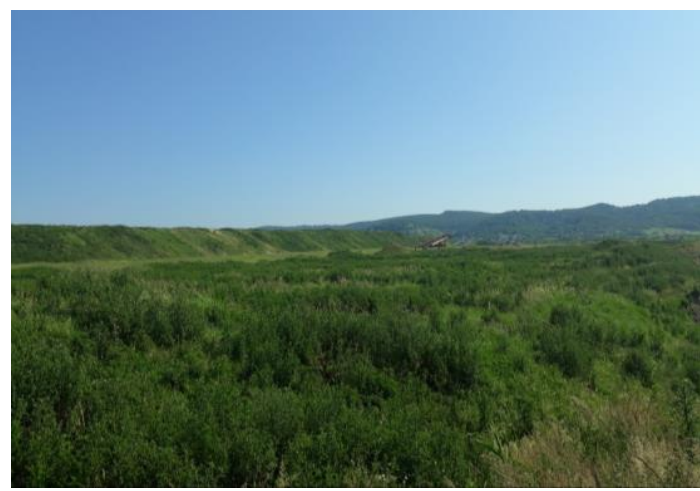

Figure 12. The inner dump of the South Peșteana open-pit revegetated 
Horsetail (Equisetum arvense) is an unpretentious plant, which adapts very easily to harsh conditions, such as degraded mining lands. It occupies relatively large areas of land, making a first fixation of the rocks and preparing the land for the installation of herbaceous and tree vegetation. This vegetation contributes to the fixation of the land through roots and enriches the land with organic material, followed by the gradual restoration of the soil that provides, in time, the basis for the installation of the vegetation characteristic to the region. This process can take 5 to 10 years or even longer.

These types of vegetation do not exert a significant pressure on the final slopes, but are distinguished by the positive effects: reduces the processes of pluvial and wind erosion, fixes the land, enriches the land with organic material, etc.

\subsection{Geochemistry of the rocks}

In the case of the Peșteana mining perimeter, no rocks were found that could potentially generate acid waters.

When flooding of coal open-pits starts, the water comes in contact with coal remains in the dump or with the coal layers from the in-situ slopes. Because sulfur enters the elementary chemical composition of coal, it can generate, in contact with water, acidic water as a result of the decrease of water $\mathrm{pH}$. Although this possibility exists, the analyses performed on the water samples taken from Pesteana perimeter, does not confirm this hypothesis [11], [21].

\section{Conclusions}

From the presentation of these factors, which influence the stability of in situ and dump slopes and consequently of the flooded remaining gaps, results their interdependence and cumulative action which in most cases materializes by worsening the strength characteristics of rocks and changing the state of stress and deformations in the rock mass. A qualitative and quantitative evaluation of them is required to eliminate the negative geotechnical phenomena and especially of the landslides and plastic flows in the rock massifs.

In the studied mining perimeter (Pesteana perimeter formed by South Pesteana and North Pesteana mining perimeters), it was found that the factors influencing the velocity and duration of the flooding process are favorable for this purpose, the presence of aquifer horizons formed by aquifer rocks with open porosity, with thicknesses of meters and tens of meters, development in the meadow area of the river Jiu which contributes to natural flooding ensuring a significant inflow of water), but may create some problems in terms of slope stability as a result of the negative effect of rock humidity, the manifestation of pore water pressure and hydrodynamic pressure.

Among the factors that negatively influence the stability of in-situ and dump slopes in the Pesteana perimeter, besides hydrogeological factors, we can also list the geological ones (presence of thick sandy layers with low resistance characteristics), hydrometeorological and climatic (rock humidity variations - from saturated to dry, the appearance of cracks, fissures, the negative effect of the freeze-thaw process, rock alteration), natural mechanical (erosion processes). In the South and North Peșteana perimeters, no large landslides were recorded, only superficial landslides. In the South Peșteana mining perimeter no suffosis phenomena were recorded before or during the flooding, but in the North Peşteana perimeter several suffosis zones were reported before the flooding and possible problems could arise during the flooding process.

Among the factors that influence the stability of the slopes, anthropogenic and biotic factors have positive action in the case of Pesteana perimeter due to the appropriate dimensioning of the working and dumping steps, the spontaneous installation of vegetation on the dump, reduction or elimination of the erosion effect, etc.

As a general conclusion, the evaluation of factors influencing the flooding process is important for establishing the right measures for the recovery and reuse of former coal open-pits, so as to ensure the necessary safety condition during the flooding and also after it.

\section{Acknowledgements}

The research presented in this paper has been conducted within the RAFF project (Risk Assessment of Final Pits During Flooding) co-financed by the Research Fund for Coal and Steel (RFCS) under the Grant Agreement No-847299-RAFF.

\section{References}

[1] McCullough, C.D., \& Lund, M.A. (2006). Opportunities for sustainable mining pit lakes in Australia. Mine Water and the Environment, 25(4), 220-226. https://doi.org/10.1007/s10230-006-0136-0

[2] McCullough, C.D., Schultze, M., \& Vandenberg, J. (2020). Realizing beneficial end uses from abandoned pit lakes. Minerals, (10), 133. https://doi.org/10.3390/min10020133

[3] Schultze, M., Pokrandt, K.H., \& Hille, W. (2010). Pit lakes of the Central German lignite mining district: Creation, morphometry and water quality aspects. Limnologica, (40), 148-155. https://doi.org/10.1051/matecconf/202030500040

[4] Mborah, C.H., Bansah, K.J., \& Boateng, M.K. (2016). Evaluating Alternate Post-Mining Land-Uses: A Review. Environment and Pollution, 5(1). https://doi.org/10.5539/ep.v5n1p14

[5] Gammons, C.H., Harris, L.N., Castro J.M., Cott, P.A., \& Hanna, B.W. (2009). Creating lakes from open pit mines: processes and considerations - with emphasis on northern environments. Canadian Technical Report of Fisheries and Aquatic Sciences, 2826(IX), 106 p.

[6] Lazar, M., Faur, F., \& Apostu, I.M. (2020). Influence of the flooding speed of former lignite open pits on the stability of final slopes. MATEC Web of Conferences, (305), 00040. https://doi.org/10.1051/matecconf/202030500040

[7] Shapoval, V., Shashenko, O., Hapieiev, S., Khalymendyk, O., \& Andrieiev, V. (2020). Stability assessment of the slopes and side-hills with account of the excess pressure in the pore liquid. Mining of Mineral Deposits, 14(1), 91-99. https://doi.org/10.33271/mining14.01.091

[8] Entov, V.M., \& Malakhova, T.A. (1974). Changes in the strain-stressed state of rock bodies following changes of pressure in a liquid-saturated stratum. Mekhanika Tverdogo Tela, (6), 53-65.

[9] Abdellah, W.R., Hussein, M.Y., \& Imbabi, S.S. (2020). Rock slope stability analysis using shear strength reduction technique (SSRT) case histories. Mining of Mineral Deposits, 14(2), 16-24. https://doi.org/10.33271/mining14.02.016

[10] Goodman, R.E. (1989). Introduction to rock mechanics. New York, United States: Wiley.

[11] Apostu, I.M., Lazar, M., \& Faur, F (2020). A model to evaluate the flooding opportunity and sustainable use of former open-pits. Sustainability, 12(21), 9275. https://doi.org/10.3390/su12219275

[12] Lazăr, M. (2010). Rehabilitation of degraded land. Bucharest, Romania: Universitas.

[13] Lazăr, M., \& Faur, F. (2015). Stability and arrangement of artificial and natural slopes - calculation examples. Bucharest, Romania: Universitas.

[14] Stănciucu, M. (2018). Slopes stability. Bucharest, Romania: Tehnical.

[15] Pazdro, Z., \& Kozerski, B. (1990). General hydrogeology. Warsaw, Poland: Geological PH.

[16] Bajcar, A. (2007). Slope stability in the final phase of decommissioning of brown coal open-pit mines. Wrocław, Poland: Politechnika Wrocławska.

[17] Castendyk, D.N., \& Eary, L.E. (2009). Mine pit lakes characteristics, predictive modeling, and sustainability. Management technologies for metal mining influenced water. Littleton, Colorado: Society for Mining, Metallurgy \& Exploration. 
[18] Report on the environmental impact study, continuation of mining works in the North Pesteana perimeter proposed to be located in the extravilan/intravilan areas of Urdari, Bălteni and Plopșoru communes, Gorj county, symbol 810 - 537, Romania. (2012). Institute for Scientific Research, Technological Engineering and Lignite Mine Designs S.A. Craiova (I.C.S.I.T.P.M.L.).

[19] Report on the environmental impact study, continuation of mining works in the South Pesteana perimeter proposed to be located in the extravilan/intravilan areas of Urdari, Plopșoru and Turceni communes, Gorj county, symbol 810 - 538, Romania. (2012). Institute for Scientific Research, Technological Engineering and Lignite Mine Designs - S.A. Craiova (I.C.S.I.T.P.M.L.).

[20] Nyari Apostu, I.M. (2019). Researches regarding the geotechnical risks in conditions of flooding of former lignite quarries. Doctoral Thesis. Petroșani, Romania.

[21] Fodor, D. (2011). Gravel pits and quarries. Bucharest, Romania: AGIR
[22] Apostu, I.M., Lazar, M., \& Faur, F. (2020). Analysis of liquefaction risk of sterile material in the inner dump of North Pesteana quarry in the conditions of flooding of the remaining gap. MATEC Web of Conferences, (305), 00005. https://doi.org/10.1051/matecconf/202030500005

[23] Herman, M.W., Hayes, G.P., Smoczyk, G.M., Turner, R., Turner, B., Jenkins, J., \& Villaseñor, A. (2015). Seismicity of the Earth 1900-2013 Mediterranean Sea and vicinity. Open-File Report. https://doi.org/10.3133/ofr20101083Q

[24] National Institute for Research - Development for Earth Physics. (accessed on October 2020). http://www.infp.ro/index.php

[25] Ministerial Order No. 2465/08.08.2013 approved by the Order of the Vice Prime Minister, Minister of Regional Development and Public Administration, No. 2956. (2019). Ministerial Order for the approval of the Technical Norm P100-1-Seismic Design Code - Part I. Published in the Official Gazette of Romania, No.558bis/03.09.2013 and 928/18.11.2019.

\section{Фактори, що впливають на процес обводнення колишніх вугільних кар'єрів}

\section{М. Лазар, І.М. Апосту, Ф. Фаур, І. Ротуньяну}

Мета. Визначення основних факторів, що впливають на процес затоплення колишніх кар'єрів для забезпечення якнайшвидшого переходу до майбутнього використання земель та безпеки об'єктів і місцевого населення.

Методика. Встановлення трьох категорій факторів, що впливають 3 кількісної та якісної точки зору на затоплення залишених пустот кар'єрів. Аналіз ключових факторів процесу затоплення залишених щілин з точки зору їх вкладу в скорочення або збільшення тривалості паводку і у зменшення або збільшення запасу стійкості різних типів схилів. Вплив і взаємодія факторів вивчалися по периметру гірничого відводу кар'єра Пештеана.

Результати. Взаємозалежність і кумулятивна дія факторів, що впливають на процес затоплення відпрацьованих пустот і на стійкість укосів і відвалів, призводить до погіршення міцності гірських порід та зміни напруженого стану і деформацій в гірському масиві. Виявлено, що по периметру Південного і Північного Пештеана не було зафіксовано великих зсувів до або під час повені, однак в Північному Пештеані відмічається кілька зон суфозії до затоплення, і можливі проблеми могли виникнути під час процесу затоплення. Встановлено, що серед факторів, що впливають на стійкість схилів, антропогенні та біотичні фактори мають позитивну дію у випадку периметра Пештеана через відповідні розміри робочих і відсипаних ступенів, самовільного зародження рослинності у відвалі, ефекту ерозії та ін.

Наукова новизна. Встановлено взаємозв'язок між ключовими факторами та їх впливом на процес затоплення, стійкість і коефіцієнт безпеки укосів в умовах кар'єру Пештеана.

Практична значимість. Отримані результати корисні для дослідників, інженерів, проектувальників гірничих робіт, місцевої влади та студентів у контексті отримання важливої інформації протікання процесу затоплення колишніх кар'єрів і прогнозу непередбачених геотехнічних явищ.

Ключові слова: кар'єр, відпрачьовані порожнини, затоплення, швидкість, тривалість, стійкість укосів, фактори впливу

\section{Факторы, влияющие на процесс обводнения бывших угольных карьеров}

\section{М. Лазар, И.М. Апосту, Ф. Фаур, И. Ротуньяну}

Цель. Определение основных факторов, влияющих на процесс затопления бывших карьеров для обеспечения скорейшего перехода к будущему использованию земли и безопасности объектов и местного населения.

Методика. Установление трех категорий факторов, влияющих с количественной и качественной точки зрения на затопление оставшихся пустот карьеров. Анализ ключевых факторов процесса затопления оставшихся щелей с точки зрения их вклада в сокращение или увеличение продолжительности паводка и в уменьшение или увеличение запаса устойчивости различных типов склонов. Влияние и взаимодействие факторов изучалось по периметру горного отвода карьера Пештеана.

Результаты. Взаимозависимость и кумулятивное действие факторов, влияющих на процесс затопления отработанных полостей и на устойчивость откосов и отвалов, приводит к ухудшению прочностных характеристик горных пород и изменению напряженного состояния и деформаций в горном массиве. Выявлено, что по периметру Южного и Северного Пештеана не было зафиксировано крупных оползней до или во время наводнения, однако в Северном Пештеана отмечается несколько зон суффозии до затопления, и возможные проблемы могли возникнуть во время процесса затопления. Установлено, что среди факторов, влияющих на устойчивость склонов, антропогенные и биотические факторы имеют положительное действие в случае периметра Пештеана из-за соответствующих размеров рабочих и отсыпных ступеней, самопроизвольного зарождения растительности в отвале, эффекта эрозии и др.

Научная новизна. Установлена взаимосвязь между ключевыми факторами и их влиянием на процесс затопления, устойчивость и коэффициент безопасности откосов в условиях карьера Пештеана.

Практическая значимость. Полученные результаты полезны для исследователей, инженеров, проектировщиков горных работ, местных властей и студентов в контексте получения важной информации протекания процесса затопления бывших карьеров и прогноза непредвиденных геотехнических явлений.

Ключевые слова: карьер, отработанные полости, затопление, скорость, продолжительность, устойчивость откосов, факторы влияния 